\title{
Development and performance of timber REITs in the United States: a review and some prospects
}

\author{
Srijana Baral and Bin Mei
}

\begin{abstract}
Timber real estate investment trusts (REITs) are companies that own and manage timberland and generate revenue by harvesting and selling timber or other forest-related products. Due to their popularity with investors, timber REITs in the United States have attracted growing research interest in the recent decades. This necessitates a review of existing knowledge on the evolution of timber REITs and their financial performance over the years. In this review, we summarize the history and development of timber REITs, discuss the tax policies applicable to timber REIT growth and their implications. We also review past studies that focused on the financial performance of timber REITs and synthesize the methodologies used in those studies. At the end, we posit the possibility of consolidation waves in the timber industry and identify some opportunities for future research. This review can shed some new light on the evolution of public timber REITs and their financial performance.
\end{abstract}

Key words: forest finance, real estate, timber industry, timberland investment, timber taxation.

Résumé : Les sociétés de gestion d'actifs forestiers (SGAF) sont des compagnies qui possèdent et aménagent des territoires forestiers dans le but de générer des revenus grâce à la vente de bois ou d'autres produits de la forêt. En raison de leur popularité auprès des investisseurs, les SGAF aux États-Unis ont suscité un intérêt de recherche croissant au cours des dernières décennies. Cela exige un recensement des connaissances existantes en lien avec l'évolution des SGAF et leur performance financière au fil des années. Dans cette revue, nous résumons l'historique et le développement des SGAF, et discutons des politiques fiscales applicables à la croissance des SGAF et de leurs conséquences. Nous passons également en revue les études antérieures axées sur la performance financière des SGAF et nous synthétisons les méthodologies utilisées dans ces études. En conclusion, nous avançons la possibilité qu'il y ait des vagues de consolidation dans l'industrie du bois. Nous présentons aussi les opportunités pour des recherches futures. Cette revue peut apporter un éclairage nouveau sur l'évolution des SGAF publiques et leur performance financière. [Traduit par la Rédaction]

Mots-clés : finances forestières, immobilier, industrie forestière, investissement forestier, taxation du bois.

\section{Introduction}

In the United States (US), forestland comprises about 310 million ha, representing $34 \%$ of the total land area in the country. Of which, about 208 million ha are considered commercial timberlands with an estimated market value of $\$ 460$ billion (US dollars) (Newell and Eves 2009; Oswalt et al. 2019). The US South, in particular, holds $41 \%$ of the US timberlands and produces roughly $60 \%$ of total timber in the country (Brandeis and Hodges 2015; Prestemon et al. 2015). Regarding timberland ownership in the US, about 145 million ha are privately owned and roughly 63 million ha are public (Oswalt et al. 2019). These timberlands provide a myriad of ecosystem services to the American people in terms of clean water, outdoor recreation and many more. Therefore, the forest sector makes a significant contribution to the overall economy of the US.

Timberland investment is the acquisition and management of timberland for the production and sale of timber or other forestrelated products. There are three common ways to invest in timberland: (i) direct purchase and management; (ii) investment funds via intermediaries, such as timberland investment management organizations (TIMOs), that manage timberland for investors; and (iii) owning stocks of publicly traded timber firms (Mendell et al. 2007). These vary in terms of participation in timberland management, liquidity, and control. Direct investment involves active timberland management and offers high control but low liquidity, whereas timber REIT investment does not involve active participation and offers very limited control but high liquidity (Fu 2017). The third option to invest in timberland is accessible to investors of all levels because it often requires lower initial investment than the first two. Since the 1980s, timberland ownership has shifted from vertically integrated forest products companies to TIMOs and timber real estate investment trusts (REITs). These two entities gradually gained popularity especially in largescale transactions in timberland investments and increased competitiveness in the forestland market (Mei 2019; Kuusela and Lintunen 2019).

REITs are companies that own or finance income-producing real estate properties. The US Congress authorized the organizational form of REIT in 1960, which allowed all the investors to invest in real estate properties. To maintain a REIT status, companies should satisfy asset, income source, dividend distribution,

Received 25 March 2021. Accepted 9 June 2021.

S. Baral and B. Mei.* Warnell School of Forestry and Natural Resources, University of Georgia, 180 E. Green Street, Athens, GA 30602, USA.

Corresponding author: Srijana Baral (email: Srijana.Baral@uga.edu).

${ }^{*}$ Bin Mei served as an Associate Editor at the time of manuscript review and acceptance; peer review and editorial decisions regarding this manuscript were handled by Eric Hansen.

(C) 2021 The Warnell School of Forestry and Natural Resources, University of Georgia. Permission for reuse (free in most cases) can be obtained from copyright.com. 
Table 1. Publicly traded timber real estate investment trusts (REITs) in the United States.

\begin{tabular}{llllcccc}
\hline Timber REIT & $\begin{array}{l}\text { Inception } \\
\text { year }\end{array}$ & $\begin{array}{l}\text { Acreage } \\
(\mathrm{mm} \mathrm{ha})\end{array}$ & $\begin{array}{l}\text { Land } \\
\text { location }\end{array}$ & $\begin{array}{l}\text { Total assets } \\
(\mathrm{mm} \mathrm{\$ )}\end{array}$ & $\begin{array}{l}\text { Total revenue } \\
(\mathrm{mm} \mathrm{\$ )}\end{array}$ & $\begin{array}{l}\text { Net income } \\
(\mathrm{mm} \$)\end{array}$ & $\begin{array}{l}\text { Market capitalization } \\
(\text { billion \$)* }\end{array}$ \\
\hline Rayonier & 2004 & 1.1 & 10 states & 3728 & 859 & 37 & 4.2 \\
PotlatchDeltic & 2006 & 0.7 & 6 states & 23 & 1040 & 166 & 2.9 \\
Weyerhaeuser & 2010 & 4.3 & 18 states & 16311 & 7532 & 797 & 22.5 \\
CatchMark & 2014 & 0.2 & 5 states & 607 & 104 & $(17)$ & 0.5 \\
\hline
\end{tabular}

Note: Data come from company websites or 2020 10-K reports. Outside the US, Rayonier manages 0.2 million ha of timberlands in New Zealand and Weyerhaeuser manages 5.7 million ha of timberlands in Canada.

*Stock price times total shares outstanding as of 31 December 2019 (WRDS 2020).

Fig. 1. Area of timberlands in thousands of hectares (shades of green) managed by current timber real estate investment trusts (REITs) in different states of the United States. Rayonier and CatchMark have the largest timberlands in Georgia (272.4 ha and 101.2 ha) and smallest in Arkansas (2.4 ha) and Florida (0.2 ha), respectively. PotlatchDeltic holds largest timberlands in Arkansas (373.8 ha) and smallest in Louisiana (2.4 ha). Weyerhaeuser has largest timberlands in Oregon (588.5 ha) and smallest in Wisconsin (1.2 ha). State level timberland data come from 2020 10-K reports of each timber REIT (CatchMark 2020; PotlatchDeltic 2020; Rayonier 2020; Weyerhaeuser 2020) and shapefiles for the US States come from 'maps' package in R programming language (Becker and Wilks 2018). [Colour online.]

Rayonier

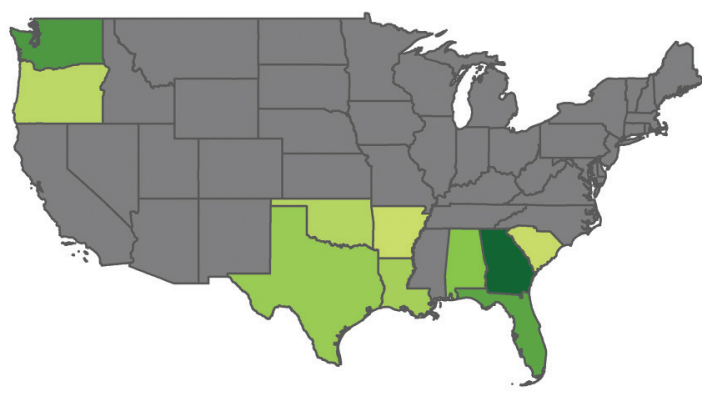

Weyerheauser

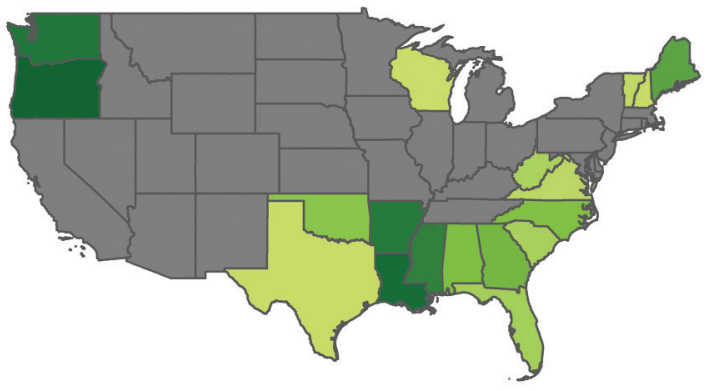

and ownership and management structure requirements imposed by the federal tax law. The major criteria of the Internal Revenue Code in the Sections $856-860$ are (i) at least $75 \%$ of all assets and gross income must be in real estate, and less than $25 \%$ of assets in taxable REIT subsidiaries; (ii) at least $90 \%$ of taxable income must be distributed to REIT shareholders as dividends; (iii) must have at least 100 shareholders for 1-year-old REIT; and (iv) REITs must be taxable as a domestic corporation. For tax purposes, REITs can deduct all distributed dividends from their taxable income so as to eliminate federal income taxes, and shareholders must pay taxes on dividends and capital gains at ordinary income tax rates and capital gain tax rates, respectively (Corgel et al.1995; Congressional Research Service 2016).

Since 1970, REITs have been growing rapidly due to high demand from investors. The number of REITs in the US increased from 34 in 1971 to more than 225 in 2020 with a corresponding market capitalization of $\$ 1.5$ billion to more than $\$ 1$ trillion (Sun 2013a; NAREIT 2020). Currently, the US REIT market has become the most established in the world. The National Association of
PotatchDeltic

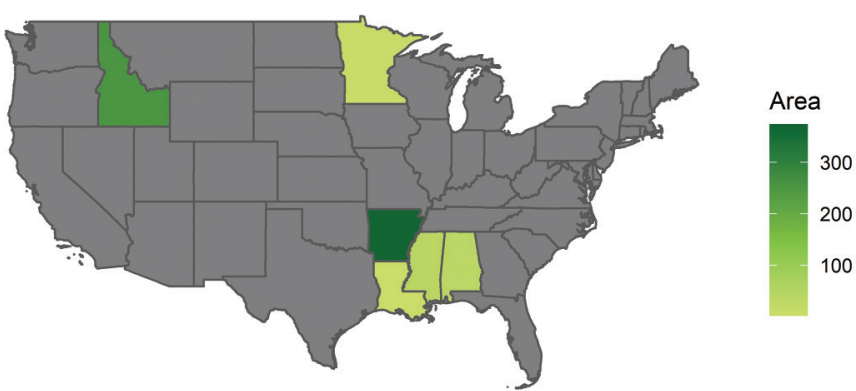

CatchMark

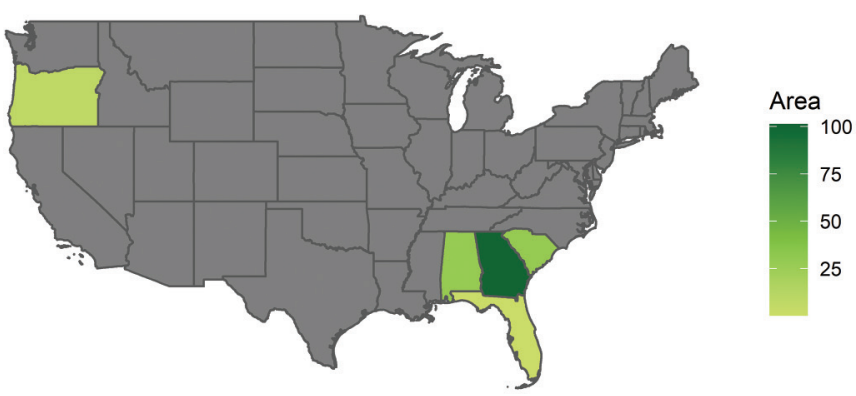

Real Estate Investment Trusts categorizes REITs into three broad classes (equity, mortgage, and hybrid REITs) and 12 property sectors (office, industrial, retail, lodging, residential, timberland, health care, self-storage, infrastructure, data center, diversified, and specialty REITs). Out of these property sectors, this review focuses on publicly traded timberland REITs, or timber REITs in short. Currently, there are four timber REITs in the US, which are Rayonier, PotlatchDeltic, Weyerhaeuser, and CatchMark (Table 1). Altogether, these timber REITs manage over 6 million ha of timberlands in 20 states across several regions of the US (Fig. 1). Pine plantations in the Southeast, conifer plantations in the Pacific Northwest, and mixed hardwood stands in the Northeast are the main concentrations of timber REIT holdings (Table 2). As of 2014 , timber REITs managed about $4.2 \%$ of total timberlands in the US and this has been increasing on a yearly basis (Hood et al. 2015). Today, the combined market capitalization of timber REITs surpasses $\$ 30$ billion or about $6 \%$ of the total market capitalization of publicly traded REITs in the US (Stevenson 2013; NAREIT 2020). 
Table 2. Tree species distribution in different timberland regions of timber real estate investment trusts (REITs).

\begin{tabular}{|c|c|c|}
\hline Timber REIT & Region & Species \\
\hline Rayonier & South & $\begin{array}{l}\text { Two thirds of the land is dominated by pine plantations such as loblolly and slash pine. Remaining } \\
\text { one-third consists of natural pine and a variety of hardwood species. Around } 67 \% \text { of timberlands } \\
\text { are planted or plantable in this region. }\end{array}$ \\
\hline PotlatchDeltic & North & $\begin{array}{l}\text { Consists of softwood species such as Douglas-fir, grand fir, and inland red cedar. Other species } \\
\text { include ponderosa pine, western white pine, aspen, red pine, and hardwoods. }\end{array}$ \\
\hline \multirow[t]{3}{*}{ Weyerhaeuser } & North & $\begin{array}{l}\text { Comprises a mix of temperate broadleaf hardwoods ( } 60 \% \text { of inventory) and mixed conifer species } \\
\text { ( } 40 \% \text { of inventory) that include American beech, birch, cedar, maple, cherry, hemlock, oak, spruce, } \\
\text { and red and white pine. }\end{array}$ \\
\hline & South & Around $76 \%$ of standing inventories are southern yellow pines and remaining $24 \%$ are hardwoods. \\
\hline & West & $\begin{array}{l}\text { Timberlands in the west are dominated by Douglas-fir and cedar (roughly } 79 \% \text { of inventory). Other } \\
\text { species include noble-fir, ponderosa pine, red alder, western larch, Sitka spruce, etc. }\end{array}$ \\
\hline
\end{tabular}

Note: Information about species distribution comes from 2020 10-K reports of each timber REIT.

In the finance and forestry disciplines, there has been literature synthesis of REITs, timberland investments, and timberland transaction costs. Corgel et al. (1995) reviewed literature on REIT investment decisions, financing decisions, and risk return issues. They found varying REIT performance due to different sample periods and performance measurement approaches. Mei (2019) synthesized timberland investment literature within the following themes: (i) investment vehicles and return indices; (ii) role of timberland in a portfolio; (iii) asset pricing of timberland; (iv) public timber REITs; and $(v)$ decision-making under uncertainty, especially with the emerging woody bioenergy market. Hiegel et al. (2020) discussed the importance of understanding timberland transaction costs and due diligence for effective evaluation of their impacts on timberland values, timber supply, and sustainable timber management. Chudy and Cubbage (2020) provided a review of timberland as an alternative asset class and found that expected returns, portfolio diversification, inflation hedging, and liquidity and risks were the key factors affecting forestry investments. Overall, these review articles have advanced our knowledge on the general aspects of REITs and timberland investments. Timber REITs are increasing in size and popularity; however, a thorough literature review of empirical analyses on timber REITs is still lacking. Hence, our goal is to fill this knowledge gap by summarizing the relevant literature on timber REITs published since 1999, the year when the first timber REIT was established in the US. This study could provide valuable insights into the financial performance of timber REITs and identify some research trends. The rest of this article is organized as follows: section 2 provides the methods of literature search; section 3 explains the development of timber REITs along with a short profile of each timber REIT; section 4 discusses tax implications for timber REITs; section 5 reviews the financial performance of timber REITs; section 6 summarizes empirical methods used in the past studies; and the last section concludes the article.

\section{Methods}

To identify existing literature on timber REITs, we performed a systematic online database query followed by a comprehensive bibliography section search of each literature. We focused the literature search on English-written articles on timber REIT evolution, tax policies, financial performance, asset pricing, and risk evaluation. First, we searched peer-reviewed articles in major online databases such as Google Scholar and Web of Science with key words "timber REIT", "timberland investment", and "public timberland asset". In this round, we selected articles based on
Table 3. List of reviewed journals that published articles related to real estate investment trusts.

\begin{tabular}{llc}
\hline Research field & Journal & $\begin{array}{l}\text { No. of } \\
\text { articles }\end{array}$ \\
\hline Forestry & Forest Policy and Economics & 10 \\
& Journal of Forestry & 4 \\
& Forest Science & 3 \\
& Journal of Forest Economics & 3 \\
& Canadian Journal of Forest Research & 2 \\
& Forest Products Journal & 2 \\
Real estate, finance, & Others (with single publication)* & 4 \\
and economics & Journal of Real Estate Portfolio Management & 3 \\
& Others (with single publication)* & 2 \\
Total & & 9 \\
\hline
\end{tabular}

"Journal details are in the reference section.

title, abstract, and keywords. Second, we searched the bibliography sections of selected articles from the first round to collect more publications on timber REITs. For this, we examined the title of each publication in the bibliography section and checked the content in the text where they have been cited. After a careful assessment of 117 collected articles, we reviewed 42 articles related to timber REIT analysis. The majority of the reviewed articles were from publications in Forest Policy and Economics, Journal of Forestry, Forest Science, Journal of Forest Economics, Journal of Real Estate Portfolio Management, Canadian Journal of Forest Research, Forest Products Journal, and Journal of Real Estate Research (Table 3). We accessed all the articles through the University of Georgia library. Additionally, we visited the individual timber REIT websites and collected their $10-\mathrm{K}$ reports to gather more historical information about their businesses. We calculated the market capitalization of each timber REIT as total shares outstanding times price per share as of 31 December 2019, with all data obtained from Wharton Research Database Services (WRDS 2020).

\section{Development of timber REITs in the US}

Timber REITs are specialized REITs that own and manage timberland and generate significant revenue by harvesting and selling timber or other forest-related products. Qualification of timberland as a REIT was possible because of the 1997 Real Estate Investment Trust Simplification Act, which repealed the 30\% gross income tax rule (Caulfield and Flick 2000). Until the early 
20th century, forest products companies owned most of the industrial timberlands in the US. However, such companies sold their timberlands or converted themselves into REITs over the past few decades. As a consequence, by 2006 , roughly $80 \%$ of the industrial timberlands were classified as a TIMO and REIT (Smith et al. 2009). In terms of timber growing regions, the US South witnessed the most significant changes in timberland ownership (Clutter et al. 2005).

Timber REIT conversions gained popularity for several reasons. First, unlike the traditional C-Corporation structure, timber REIT income is taxed only once at the shareholder level. At the corporate level, REITs can deduct dividends from their taxable income and thus do not owe corporate tax. This makes timber REIT a relatively tax-efficient alternative of timberland investment. Second, timberland assets are recognized by their book values or historical transaction prices according to the US generally accepted accounting principles, which are often much less than their fair market values, especially under vertically integrated forest products companies. However, timber REITs alleviate this undervaluation problem by incorporating more frequent and recent transaction information into the current pricing of their timberlands (Piao et al. 2017). Another reason for REIT conversion is liquidity and transparency of timber REITs. Financial information of timber REITs is routinely disclosed to the general public via registration statements, periodic reports, and other forms filed to the US Securities and Exchange Commission.

Plum Creek was the first timber REIT in the US, converted from a Master Limited Partnership in 1999. Realizing several advantages of REITs over other forms of securitized ownerships, more forest products firms completed conversions over the years, e.g., Rayonier in 2004, Potlatch and LongView Fibre in 2006, Weyerhaeuser in 2010, and CatchMark in 2014 (Hunt 2012; Mendell 2016). LongView Fibre remained as a timber REIT only between January 2006 and April 2007. Currently, there are four timber REITs in the US: Rayonier, PotlatchDeltic, Weyerhaeuser, and CatchMark.

Rayonier started business as the Rayonier Pulp and Paper Company in Washington in 1926. Before becoming International Telephone and Telegraph (ITT) Rayonier in 1968, a subsidiary of ITT Corp, the company invested in the southeast timberland and established a couple of pulp mills. Rayonier was spun off from ITT Corp and began to trade on the New York Stock Exchange in 1994. Later in 2004, Rayonier completed REIT conversion and operated its core businesses in forest resources, real estates, and performance fibers. In 2014, the performance fibers business was spun off from Rayonier to become an independent public company as Rayonier Advanced Materials. In 2020, Rayonier acquired Pope Resources for $\$ 656$ million. With $\$ 3.7$ billion in total assets, Rayonier generated a total revenue of $\$ 859$ million and a net income of \$37 million as of 2020 (Rayonier 2020).

Potlatch was founded in 1903. During the great depression in the mid-1950s, the company merged with other timber and lumber companies into Potlatch Forests, Inc., to overcome their financial challenges and to increase their pulp and paperboard production. Potlatch Forests, Inc., merged with more paper companies and plywood mills and converted into the Potlatch Corporation in 1973. In 2006, Potlatch completed REIT conversion and focused its activities on timberlands, wood products, and real estate businesses. Pulp-based businesses were spun off into an independent company from Potlatch in 2008. Potlatch acquired more timberlands in 2015 and merged with Deltic Timber in 2018, thus changing its name to PotlatchDeltic Corporation. With $\$ 2.3$ billion in total assets, PotlatchDeltic generated a total revenue of $\$ 1$ billion and a net income of \$166 million as of 2020 (PotlatchDeltic 2020).

Weyerhaeuser began timberland business in 1900 in Washington. It established several mills for pulp, board, plywood, woodfiber, and bark processing between 1945 and 1949. Additionally, the company purchased large timberland in the US South in 1956 and again in 1969. Public trading began on the New York Stock Exchange in 1963. The company expanded its real estate business by acquiring more real estate in 2006, all of which, however, were sold in 2014. To become a more competitive timberland owner and operator, Weyerhaeuser completed timber REIT conversion in 2010. In 2013, it acquired 261022 ha of timberland from Longview Timber and in 2016, it merged with Plum Creek. With $\$ 16.3$ billion in total assets, Weyerhaeuser generated a total revenue of $\$ 7.5$ billion and a net income of $\$ 797$ million as of 2020. Weyerhaeuser is the largest timber REIT in the US that operates more than 38 wood products manufacturing (Weyerhaeuser 2020).

CatchMark, formerly a TIMO named as Wells Timberland, has been owning and managing timberland since 2007. It purchased around 12140 ha of timberlands in 2012 and went public on New York Stock Exchange the following year. With $\$ 0.6$ billion in total assets, CatchMark generated a total revenue of $\$ 104$ million and a net income of -\$17 million as of 2020 (CatchMark 2020).

\section{Tax as a factor of timber REIT growth and its implications}

After REIT establishment by the Cigar Excise Tax Extension Act of 1960, reformation of several tax laws reinforced REIT growth over time. First, the 1976 Tax Reform Act allowed REITs to hold properties for sale and to avoid taxes on income generated from that sale. Then, the 1986 Tax Reform Act repealed the 5/50 rule for REIT's first taxable year, allowed capturing of paid fees, and removed tax advantages of other real estate investment vehicles, thus making REIT conversion easier. All these changes contributed smooth development and operation of REIT as an active investment (Hunt 2012). The Omnibus Budget Reconciliation Act of 1993 relaxed REIT shareholder ownership constraints by modifying the $5 / 50$ rule for pension funds, which increased attractiveness of REITs to pension funds (Friday et al.1999). In addition, the 1997 Real Estate Investment Trust Simplification Act eliminated three tax provisions affecting REITs: (i) rule associated with disqualification of REIT rental income for tax purposes, (ii) tax on retained capital gains, and (iii) rule on $30 \%$ gross income from the asset sale. Later in 1999, the REIT Modernization Act allowed REITs to own taxable subsidiaries that would not previously qualify as a rental income (Chan et al. 2003). All such new tax legislations that were also associated with timberland firms were viewed as drivers of timberland ownership change from forest products companies to timber REITs.

Since REITs started owning timberlands, more tax laws related to timber REITs were passed or proposed. In 2003, the Jobs and Growth Tax Relief Reconciliation Act reduced maximum capital gain tax from $20 \%$ to $15 \%$ for timber sold between 2003 through 2009. Prior to reducing safe harbor timberland transaction holding time to 2 years by the Timber Revitalization and Economic Enhancement Act of 2008, the American Jobs Creation Act of 2004 modified the safe harbor rule for timber REIT. This rule made disposals of underlying assets (timber sale) an unforbidden transaction, as received by REITs in general (National Timber Tax 2020). The 2008 act relaxed three other timber REIT provisions on timber transactions: (i) considered timber gain as a real property sales and as a qualified income under section 631(b) and section 631(a), respectively, if timber harvest was within taxable REIT subsidiary; (ii) counted mineral loyalty income as a "good" income for the REIT income test purpose for those properties previously associated with timber production; and (iii) increased securities of taxable REIT subsidiaries from $20 \%$ to $25 \%$ of a REIT's asset value (Mendell and Sydor 2008). These provisions further increased attractiveness of timber REIT investments among institutional investors and eased conversion of forest products companies into timber REITs. 
Additionally, several tax proposals affecting timber REITs had been introduced in the Congress. For example, Representative David Camp released the 2014 Tax Reform Act draft proposal to exclude timber as a real estate for REIT taxation purpose or to treat REIT as a corporation where the double taxation rule applies. Other similar proposals that were released in the Congress did not come to fruition, but they could possibly serve as a baseline for future tax reform bills. While the financial effects of tax reform acts or proposals have been analyzed in the past for private timber REITs and family forest owners (Cushing 2006; Cushing and Newman 2018; Baral et al. 2020), studies evaluating their impacts on public timber REITs are scarce. Sedjo and Sohngen (2015) used timber supply model to analyze the effects of the 2014 proposed federal tax laws on costs and net returns of public timber REITs and found negative impacts on investors. At the top individual tax rates of $39.6 \%$ and $35 \%$, costs increased, respectively, by $31 \%$ at $35 \%$ maximum corporate tax rate and by $24 \%$ at $25 \%$ maximum tax rate. Additionally, the removal of favorable capital gain tax provision and the elimination of REIT as a legal business form of timberland ownership increased tax on harvested timber by $20 \%$.

The 2017 Tax Cuts and Jobs Act reformed several federal income tax laws applicable to timber sector. The act retained treatment of timberland as a real property and introduced a new rule on REIT dividend deduction that allows $20 \%$ of "qualified business income" deduction, thus reducing shareholders' taxes on REIT dividends (Internal Revenue Service 2020). Looking forward, more changes on timber REIT tax rules may take place.

\section{Financial performance of timber REITs}

REIT conversions and inclusion of timber REITs in a portfolio have attracted many researchers to study financial performance and investment decisions of timber REITs. Additionally, the wealth of return data has provided unique opportunities to infer underlying characteristics of timber REITs through financial modeling. With the shift in timberland ownership, Mendell et al. (2008) and Piao et al. (2017) evaluated, respectively, the short- and long-term market reactions to timber REIT conversions. Mendell et al. (2008) evaluated four timber REITs (Plum Creek, Rayonier, Potlatch, and LongView Fibre) conversion announcements between 1999 and 2006, and found a significant short-term abnormal return, indicating investor's preference of holding industrial timberland within REITs in the short run. In their study, Piao et al. (2017) excluded LongView Fibre and included Weyerhaeuser and employed four approaches and three benchmarks to compute abnormal returns. Their results corroborated those of Mendell et al. (2008), showing significant long-term abnormal returns. Therefore, the structural changes in the timber sector have added values to timber firms in both the short and long runs.

Sun et al. (2013) categorized changes in industrial timberland ownership into four groups, which included seven timber REIT conversion announcements and four land acquisitions by timber REITs, and assessed their impacts on the financial performance of forest firms. Again, the positive abnormal returns were significant for timber REIT conversion announcements. However, land acquisitions by timber REITs generated weak and negative abnormal returns. Moreover, the asset volatility increased for all groups except for the land acquisition by timber REITs. Observation of timber REIT conversions through the lenses of sustainable forestry has generated concerns in regard to environmental impacts induced by new forest management regime. Fernholz et al. (2007) pointed out that conservation easements and forest certification were some of the tools to address such issues for resource protection, risk reduction, and asset enhancement.

Using the parametric and non-parametric approaches, Mei and Clutter (2010) assessed the financial performance of public-equity timberland investments consisting of timber REITs and other types of public timber firms. Public-equity timberland performed similar to the market and was unable to diversify risk. The authors suspected that the REIT conversions by Plum Creek, Rayonier, and Potlatch caused overall decreasing trend in systematic risk. Moreover, they reported a minimal impact of gloomy market on the systematic risk during the subprime residential mortgage blowup. The results from another study by Wan et al. (2013) corroborated the results in Mei and Clutter (2010).

The great recession of 2007-2009 is regarded as the most significant economic downturn in the US history. The collapse of the US housing market led to contraction of liquidity in financial markets and generated financial turmoil. Such events unavoidably affected timber REITs in the country. Sun (2013a) evaluated time-varying risk of timber REITs for the 2007-2009 recession period. They selected a combination of generalized autoregressive conditional heteroscedasticity (GARCH) model and extreme value theory after assessing four alternative risk measurement approaches. The results showed $99 \%$ of absolute daily value-at-risk between $5.03 \%$ and $8.32 \%$, and daily losses up to $13 \%$ of timber REIT investments due to market volatility. Using similar approaches, Sun (2013c) examined the relation between price variation and trading volumes of three timber REITs. The GARCH model showed a positive correlation between conditional volatility of asset returns and abnormal trading volumes. This implied that the same underlying information flow influenced returns and volumes of timber REITs. The bivariate extreme value models revealed a positive relation between absolute values of return and trading volumes. During extreme market movements, the return-volume relation of timber REITs was not very strong and stable. Regarding returnvolume relation in the tail, the positive association was stronger during the market stress (lower tail) than that during the market boom (upper tail) for some timber REITs, thereby signifying somewhat symmetric relationship. In the equity market, assessment of price-volume relation of public firms is primarily useful to understand financial market structure, mechanism of information flow, and market price volatility measured by trading volume (Karpoff 1987; Chen et al. 2001).

In general, REITs are recognized as an investment vehicle with portfolio diversification abilities (Wechsler 2013). Regarding the diversification benefits of timberland assets, several studies found low correlations between the timberland investments and the stock market (Sun and Zhang 2001; Cascio and Clutter 2008). La and Mei (2015) investigated portfolio diversification through timber REITs and found no general trends within timber REITs or between timber REITs and the Standard and Poor's 500 (S\&P 500) index. This indicated a long-run diversification potential of timber REITs when each REIT was considered as a unique candidate. However, other shortterm studies showed fewer diversification benefits of timber REITs (Sun 2013b; Wan et al. 2013; Piao et al. 2016). With the increasing interest of investors on timber REITs for portfolio diversification, it is important to understand correlations between the stock market and the timber REITs. Understanding the basic issues associated with the theory of informational efficiency is also crucial in the financial market. Informational efficiency is the degree to which the market price incorporates all available information into an asset's value, thus facilitating better informed investment decisions. La and Mei (2013) evaluated informational efficiency of timber REITs from 1999 to 2012 and found that the timber REITs were less efficient than other forest products companies and the S\&P 500 index, implying some potential arbitrage opportunities for sophisticated investors.

Although a number of studies in the real estate domain investigated REITs of various property types, not many studies have compared performance differences between them or their immediate counterparts. For example, Benefield et al. (2009) and Ro and Ziobrowski (2011) compared diversified and specialized REITs and reported better performance of diversified equity REITs based on the overall market conditions during the given sample period. Such comparative studies remain an interesting topic for REITs of 
other property types. In forest finance, a number of studies investigated and compared various aspects of timber REITs with private timberland markets, other forms of securitized ownership, other REITs, and lumber future prices (Mei and Clutter 2010, 2020; Sun 2013c; Piao et al. 2016; Clements et al. 2017).

In contrast to private-equity timberland, public-equity timberland could not outperform the market and had higher systematic risk (Mei and Clutter 2010). This suggested limited potential of timber REITs in improving the efficient frontier. Scholtens and Spierdijk (2010) also showed no improvement in mean variance frontier when public timberland assets were included in the portfolio. Along the same line, Sun (2013b) confirmed that the timber REIT structure introduced unavoidable systematic risk into timberland investments and provided limited diversification benefits than private-equity timberland. Under the mean conditional value-at-risk framework, Restrepo et al. (2020) revealed time varying role of timberland in a mixed-asset portfolio and more diversification benefits of private-equity timberland. Regarding the inflation hedging, Wan et al. (2013) found strong and consistent hedging ability of private-equity timberland, and improvement in hedging ability of forest products companies only after the REIT conversions. However, Yao et al. (2014) reported higher mean excess returns of timber REITs than their private-equity counterparts that barely earned expected returns. They also underscored easy trading, liquidity, and transparency of public timber REITs over the private-equity timberlands.

Unlike Master Limited Partnerships, timber REITs do not have a fixed investment time period and provide more investment opportunities to institutional investors. When evaluating returnvolume relationships of timber REITs versus Master Limited Partnerships, Sun (2013c) found larger total standing shares, daily trading volumes, and average daily turnover rates of timber REITs. However, most of the timber REITs had weaker return-volume relation than Master Limited Partnerships under the extreme market movements. Regarding the volatility of returns, trading volumes explained only a small portion of conditional volatility of timber REIT returns. Another study compared performance differences among timber REITs, other specialized REITs, and common REITs (Piao et al. 2016). Unlike other REITs, timber REITs had the lowest unconditional variance, largest market capitalizations, no excess returns, and were least sensitive to recessionary shocks. Although timber REITs are a part of specialized REITs, they had the highest conditional volatility as opposed to other specialized REITs. Additionally, timber REITs were more vulnerable to idiosyncratic shocks and had limited portfolio diversification ability. In comparison to forest products firms, timber REITs exhibited better performance due to tax efficiency and better liquidity (Mendell et al. 2008). Yao and Mei (2015) assessed the risk-return relationship between 16 forestryrelated assets and innovations in state variables to consider risks of unfavorable shifts in the investment opportunity set. While the public-equity timberland assets, consisting of timber REITs, earned significant positive excess returns over 1988-1999, forest products and timber products earned insignificant excess returns in the whole sample period of 1988-2011.

The return indices of private- and public-equity timberland investments differ greatly with respect to financial leverage, liquidity, business segments, transactions, and geographic allocations. Considering these differences, Mei (2015b) constructed a pure-play timberland index that had pure exposure to timberland business segment of timber REITs and found that the pureplay index differed significantly from private timberland indices and that the public timber market tended to lead the private market. Recognizing the abovementioned differences between private- and public-equity timberland markets, Mei and Clutter (2020) examined returns and short-run information transition of REITs and TIMOs with full adjustments on the composition of these asset returns. The results showed higher systematic risk of timber REITs than TIMOs and only TIMOs as a risk diversifier in portfolio optimization. REIT returns helped to predict TIMO returns, and both assets exhibited positive abnormal returns. The outputs clearly showed the importance of understanding differences in return indices of the same underlying asset for better investment decisions.

Regarding the linkage between lumber prices and timberland investments, Clements et al. (2017) evaluated connectivity between lumber futures and timber REITs and found a positive relation of lumber prices and an inverse relation of capitalization rates with public timber REITs in the long run. In the short run, changes in timber REIT prices were consistent with those in the long run. Clements et al. (2011) found a similar relationship between lumber prices and private timberland values. However, lumber futures prices had a positive relationship with timber REITs, whereas unanticipated shocks in lumber prices had a negative impact on private timberland values (Clements et al. 2011, 2017). Lumber and timber prices are often correlated as lumber is derived from timber. It is a principal income producing component of timber REITs because prices of timber REITs are intrinsically connected to the value of timber grown and harvested. In general, strong lumber markets indicate strong markets for sawtimber, and vice versa. That being said, timberland investors should pay attention to lumber market conditions as well. Additionally, the strength of relationship between lumber and sawtimber prices may vary by region. Therefore, implications of lumber market conditions for timberland investment decisions should be evaluated on a regional basis.

\section{Methods used for financial analyses of timber REITs}

In this section, we discuss some common techniques used in the financial analyses of timber REITs in the US (Table 4). Capital asset pricing model (CAPM), a single-factor model introduced by Sharpe (1964) that has been widely used in the finance literature, has many applications in the timberland sector. For example, Mei and Clutter (2010) used the CAPM to assess returns of private and public timberland assets. They also estimated the CAPM in the state space framework with the Kalman filter to examine time-varying risk-adjusted excess return and systematic risk. Wan et al. (2013) used the CAPM under inflation and tested the hedging ability of private and public timberland assets. Mei (2017) used the CAPM and other asset pricing models in evaluating return indices of public and private timberland assets. Piao et al. (2017) constructed cumulative abnormal returns of timber REITs based on CAPM. Considering potential presence of stale pricing, Mei and Clutter (2020) used the CAPM with lagged market premium to evaluate return indices of TIMOs and REITs.

Given that the CAPM uses market risk as a single factor and does not consider many other risk factors in the economy that may affect asset pricing, several studies extended the past research by using multifactor asset pricing models. The Fama-French threefactor model also includes size and value risk factors given the fact that small-size and value stocks outperform large-size and growth stocks (Fama and French 1993). This model has been applied to a variety of timberland issues, including asset pricing (Mei and Clutter 2010), inflation hedging ability (Wan et al. 2013), return indices (Mei 2017), and estimation of long-term abnormal returns (Piao et al. 2017). Another multifactor asset pricing model used in evaluating timber REITs is the arbitrage pricing theory. Yao et al. (2014) used this model to estimate the expected returns of private and public timberland investments and found that it better explained timberland returns than the CAPM. They also revealed the ability of CAPM to price public-equity but not private-equity timberland assets. However, it is a much more complicated technique and requires a careful choice of factors.

A few studies have applied other multifactor asset pricing models to timberland. Yao and Mei (2015) used the intertemporal CAPM to assess risk-return relationships of forestry-related assets 
Table 4. Summary of methodologies employed in the financial analysis of timber real estate investment trusts (REITs).

Parametric (CAPM and Fama-French

three-factor models) and nonparametric

(Stochastic Discount Factor) approaches

Mean-variance approach

CAPM under inflation, and Fama-French three-factor model

Entropy measurement

Event study analysis and GARCH

GARCH and extreme value models

Copula modeling

CAPM and APT

Intertemporal CAPM

Co-integration analysis

BDS independence test and bootstrapping method

Regression-based and pure-play approaches

Intertemporal CAPM and multivariate GARCH

Buy-and-hold AR, cumulative $\mathrm{AR}^{\dagger}$, Reference

Mendell et al. 2008

Daily stock prices of PCL, RYN, LFB, and PCH for the event period of 11 days

Mei and Clutter 2010; $\quad$ Quarterly returns of PCL, PCH, and RYN from 1987Q1 Mei 2017

to $2008 \mathrm{Q} 4$, annual unleveraged returns of PCL, RYN PCH, and WY from 2010 to 2014

Scholtens and Spierdijk Quarterly returns of PCL, RYN, and PCH from 1994Q4 2010

Wan et al. 2013

La and Mei 2013

Sun et al. 2013

Sun 2013a, 2013c

Sun $2013 b$

Yao et al. 2014

Yao and Mei 2015

to $2007 \mathrm{Q} 3$

Quarterly returns of PCL, RYN, PCH, and WY from 1987Q1 to 2009Q4

Daily returns of PCL, RYN, PCH, and WY from July 1999 to December 2012

Daily returns of PCL, RYN, LFB, PCH, and WY between 997 and 2010

Daily returns and trading volumes of PCL*, RYN, and PCH between 1999 to 2010

Daily returns of PCL, RYN, LFB, PCH, and WY from 3 March 1994 to 31 December 2010

Quarterly value weighted returns of PCL, RYN, PCH, and WY from 1988Q1 to 2011Q4

Quarterly returns of PCL, RYN, PCH, and WY from 1988Q1 to 2011Q4

La and Mei 2015

Daily prices of PCL, RYN, PCH, and WY from December 2009 to December 2013

Mei 2015a

Mei 2015b

Piao et al. 2016

Piao et al. 2017

portfolio approach with

roling regression ${ }^{\ddagger}$, and panel data regression

Vector error correction model and GARCH

Augmented CAPM and bivariate vector

autoregression model

Clements et al. 2017

Mei and Clutter 2020

Quarterly returns of PCL, RYN, PCH, and WY from 1987Q1 to 2012Q4

Monthly returns of PCL, RYN, PCH, and WY from 2010 to 2014

Daily returns of PCL, RYN, PCH, and WY from

4 January 1999 to 31 December 2014

Monthly financial data of PCL, RYN, PCH, and WY for event period of one to three years

Lumber futures contract prices and quarterly prices of PCL, RYN, PCH, and WY from 1999Q3 to 2014Q4 Quarterly returns of RYN, PCH, WY, and CTT from 1999Q1 to 2017Q4

Annualized returns of RYN, PCH, WY, and CTT from 1987 to 2018
Major findings

Statistically significant positive abnormal returns.

High excess returns and performed similarly as the market, lower return and higher risk of public

timber companies than pure-play index.

No significant improvement in the mean-variance frontier.

Improvement in hedging ability of forest products companies after REIT conversions.

Less efficient to incorporate information than forest products industries and S\&P 500.

Increased volatility and statistically significant

abnormal returns for REIT conversion announcements.

Positive return-volume relation, high value at risk during the recession.

Smaller volatility of tail dependence, fewer

diversification potential.

Higher mean excess returns of public equity timberlan assets, more variations in returns explained by APT than the CAPM

More variations in cross-sectional returns explained by intertemporal CAPM, significant positive excess returns for public-equity timberland assets over 1988-1999.

Long-run diversification potential.

Independent and identically distributed public-equity timberland asset returns, average periodic return and risk remain almost constant.

Pure-play index better depicts returns on securitized timberland assets.

Intertemporal CAPM more capable in explaining cross-sectional returns of timber REITs. Larger market capitalization, no excess returns, and insensitive to recessionary shocks.

Statistically significant abnormal returns in the long term.

Positive long-run and short-run relationship between

lumber futures and timber REITs.

Insignificant positive abnormal returns, REIT returns predict TIMO returns, and higher systematic risk of timber REITs.

Weight on timberland in the mixed-asset portfolio vary with time. 
and found that the model explained $80 \%$ of the variations in the cross-sectional returns of most assets compared to the respective $5 \%$ and $37 \%$ of the variations explained by the CAPM and the FamaFrench three-factor model. Piao et al. (2016) used the same approach to evaluate and compare risk-return characteristics of timber REITs, other specialized REITs, and common REITs. The results from these studies indicated higher capability of intertemporal CAPM in explaining cross-sectional returns of timber REITs and other forestry-related assets. While timberland returns are often evaluated with several parametric approaches, Mei and Clutter (2010) and Mei (2017) introduced the nonparametric stochastic discount factor approach in pricing timberland assets and identified the importance of intertemporal consumption decisions in pricing timberland.

Other techniques, such as the mean-variance approach, copula modeling, and co-integration analysis have been used in detecting the short- and long-run correlations between timber REITs and the financial markets. Scholtens and Spierdijk (2010) applied the mean-variance framework to assess the diversification potential of timber REITs. Sun (2013b) estimated both constant and time-varying symmetrized Joe-Clayton copulas to assess association between the timber REITs and the equity market. La and Mei (2015) used the co-integration analysis, a time series technique that examines long-run relationship of different variables by identifying a common stochastic trend (Arshanapalli and Nelson 2008), to investigate diversification ability of timber REITs. Among these techniques of assessing relationship between timberland assets and market, the notion of copulas is a better approach as it overcomes limitations of correlations (Pfeifer 2013).

Several past studies have compared financial performance of private and public timberland investments under the framework of the modern portfolio theory, but have ignored the independent and identical distribution assumption that is critical to the distinction between single- and multi-period investment decisions (Newell and Eves 2009; Sun and Zhang 2001; Mei and Clutter 2010). Mei (2015a) addressed this issue by using the Brock-DechertScheinkman test and bootstrapping method and found that returns on liquid public-equity timberland assets were independent and identically distributed, whereas returns on private-equity timberland assets were not. They also pointed out that the direct comparisons of returns on private and public timberland assets can be misleading. Mei (2015b) constructed a pure-play timberland index based on public timber firms and revealed that the new benchmark tended to lead the national council of real estate investment fiduciaries timberland index. Mei (2017) compared different index construction methods of timberland investment returns, which included various national council of real estate investment fiduciaries timberland indices, transaction-based index, and a pure-play index, and offered some insightful guidance to better benchmark timber investment returns. Mei and Clutter (2020) tested information transition dynamics between TIMOs and REITs under a vector autoregression framework.

Event study is another widely used empirical analysis to assess the financial impact of a specific event. A short-term analysis tests the quickness of a market event, whereas a long-term analysis tests the lasting effect. Mendell et al. (2008) and Piao et al. (2017) used this approach to examine the short- and long-term abnormal returns of timber REIT conversions, respectively. Unlike the traditional analysis, which assumes constant variance and no serial correlation, Sun et al. (2013) assessed the event-induced abnormal returns with GARCH effects by considering a cluster of volatility over time in the financial data.

Regarding the measurement of volatility in timberland investments, GARCH models (Engle 1982) are often used. Sun et al. (2013) combined the event analysis with a GARCH model to estimate timevarying conditional volatility of timber REIT returns and compared abnormal returns obtained from this model to those without GARCH effects. Sun (2013a) combined GARCH and extreme value theory to measure market risk of individual timber REITs during the tranquil and volatile market conditions. They also used parameters estimated from this approach to compute value-at-risk for both the short and long investment positions. Sun (2013c) used the same approaches to examine price variation and volume dynamics of timber Master Limited Partnerships and REITs.

Piao et al. (2016) used multivariate exponential GARCH model, which captures the leverage effect, to compare risk and return characteristics of three types of REITs. Yao and Mei (2015) also used a GARCH model to estimate innovations in state variables in pricing forestry-related assets. Clements et al. (2017) used the vector error correction and GARCH models to investigate a connectivity between lumber futures and timber REIT prices. Restrepo et al. (2020) tested non-normal distribution of timberland returns and compared standard deviation with conditional value-at-risk as the risk metric in portfolio optimization. They concluded that standard deviation tended to underestimate the risk and conditional value-at-risk was a better risk measure.

\section{Discussion and conclusions}

In this review, we summarized the development and performance of timber REITs in the US and provided some prospects for future research. The results revealed a great expansion in timber REIT conversions, mergers, and acquisitions in the last two decades. Several factors affected the growth of timber REITs in the US: high liquidity, small amount of capital to be invested, no active management of timberland, and some tax benefits. Timber REIT success can also be linked with the housing market, as $50 \%$ to $75 \%$ of timber REIT revenue comes from wood supply for homebuilding purposes (Lerner 2015). The early literature on timber REITs provided only a general description of their business activities and the advantages and disadvantages of investing in this new securitized timberland asset. As timber REITs continued to become a popular alternative investment strategy for investors, the focus of timber REIT research revolved around the impacts of REIT conversions, risk and return characteristics of timber REITs, and their financial performances over other types of real estate.

Although tax policies associated with timberlands have undergone frequent changes in the past, not many studies have evaluated its effects on timber REIT returns. As tax is considered as one of the major drivers of timber REIT conversions, changes in tax laws and its associated effects should be closely monitored and investigated. Timber REIT conversions have received a positive market reaction and introduced non-diversifiable systematic risk into timberland investments. There is some evidence that timber REITs have diversification benefits in the long run but offer no excess returns (La and Mei 2015; Piao et al. 2016). Timber REITs also provide greater liquidity than private-equity timberlands and are more tax efficient than C-Corporations. Nonetheless, several other financial characteristics of timber REITs and private timberland need to be considered while making the investment decisions.

In recent years, increasing interest of institutional investors in timberland investment has generated a need for advanced and improved analysis of this asset class. As a result, researchers applied several asset pricing models, with the CAPM being the most widely used. However, this single-factor model has low explanatory power and low prediction accuracy on private-equity timberland. It also fails to consider time variation in expected returns and does not capture risk of unfavorable shifts in the investment opportunity set. In contrast, multifactor models such as the Fama-French three-factor model, the arbitrage pricing theory, and the intertemporal CAPM can better explain the financial characteristics of timberland and other assets (Sun and Zhang 2001; Yao et al. 2014). In addition to expected returns, volatility of returns is another important characteristic affecting investment decision. In measuring and forecasting volatility of timberland 
returns, a GARCH model is often used together with various asset pricing models.

Timber REITs own and manage a significant area of commercial timberlands in the US. Acquisitions of high-quality industrial timberland and their sustainable management is one of the major business strategies of all timber REITs. For instance, CatchMark acquired 0.4 million ha of East Texas timberland in a joint venture in 2018; Weyerhaeuser purchased around 27923 ha of highly productive timberlands in the southwest Alabama in 2021. Timber REITs are likely to pursue more timberland acquisitions in the future for cash flow generation, portfolio enhancement, and improvement of the long-term enterprise values. With the increasing concerns over climate change and carbon sequestration, timber REITs are strategizing to capitalize emerging carbon opportunities. Although future legislations about clean energy or carbon emissions are uncertain at this time, timber REITs should anticipate some effects of those legislations on their timberland operations.

More restructuring activities may take place in the form of mergers and acquisitions that enhance synergy and reduce risk. Currently, lumber prices are soaring to a record-high due to the interaction between a high demand from the housing market and a low supply from timber producers. Given that the lumber prices tend to lead timber REIT returns, surge in lumber prices may have even greater impact on timber REIT prices and performances. Looking forward, we expect more research on the financial performance of timber REITs and their comparisons with other types of real estate.

\section{Acknowledgements}

The United States Department of Agriculture grant GEOZ-0199-MS partially funded this research.

\section{References}

Arshanapalli, B., and Nelson, W. 2008. Cointegration and its application in finance. In Handbook of finance. Vol. III. Edited by F.J. Fabozzi. John Wiley \& Sons.

Baral, S., Li, Y., and Mei, B. 2020. Financial effects of the 2017 tax cuts and jobs act on nonindustrial private forest landowners: A comparative study for 10 southern states of the United States. J. For. 118(6): 584-597. doi:10.1093/ jofore/fvaa032.

Becker, R.A., and Wilks, A.R. 2018. Maps: Draw Geographical Maps. R package version 3.3.0.

Benefield, J.D., Anderson, R.I., and Zumpano, L.V. 2009. Performance differences in property-type diversified versus specialized real estate investment trusts (REITs). Rev. Financ. Econ. 18(2): 70-79. doi:10.1016/j.rfe.2008.04.001.

Brandeis, C., and Hodges, D.G. 2015. Forest sector and primary forest products industry contributions to the economies of the Southern States: 2011 update. J. For. 113(2): 205-209. doi:10.5849/jof.14-054.

Cascio, A.J., and Clutter, M.L. 2008. Risk and required return assessments of equity timberland investments in the United States. For. Prod. J. 58(10): 61-70.

CatchMark. 2020. Available from https://catchmark.com/ [accessed 19 June 2020].

Caulfield, J.P., and Flick, W.A. 2000. Prospects and challenges with securitized timberland. South. For. Econ. Work. KY. 8 pp.

Chan, S.H., Erickson, J., and Wang, K. 2003. The origins and evolution of real estate investment trusts. In Real estate investment trusts: Structure, performance, and investment opportunities. Oxford University Press, New York.

Chen, G., Firth, M., and Rui, O.M. 2001. The dynamic relation between stock returns, trading volume, and volatility. Financ. Rev. 36(3): 153-174. doi:10.1111/ j.1540-6288.2001.tb00024.x.

Chudy, R.P., and Cubbage, F.W. 2020. Research trends: Forest investments as a financial asset class. For. Policy Econ. 119: 102273. doi:10.1016/j.forpol. 2020.102273. PMID:32834769.

Clements, S., Ziobrowski, A.J., and Holder, M. 2011. Lumber futures and timberland investment. J. Real Estate Res. 33(1): 49-71. doi:10.1080/10835547.2011. 12091296.

Clements, S., Tidwell, A., and Jin, C. 2017. Futures markets and real estate public equity: Connectivity of lumber futures and timber REITs. J. For. Econ. 28: 70-79. doi:10.1016/j.jfe.2017.06.003.

Clutter, M., Mendell, B., Newman, D., Wear, D., and Greis, J. 2005. Strategic factors driving timberland ownership changes in the U.S. South. USDA Forest Service, Asheville, N.C. pp. 1-15.

Congressional Research Service. 2016. Real estate investment trusts (REITs) and the foreign investment in real property tax act (FIRPTA): Overview and recent tax revisions. Available from www.crs.gov [accessed 10 July 2020].
Corgel, B.J., Mcintosh, W., and Ott, H.S. 1995. Real estate investment trusts: a review of the financial economics literature. J. Real Estate Lit. 3(1): 13-43. doi:10.1080/10835547.1995.12090042.

Cushing, T.L. 2006. A comparison of the relative reduction in land expectation value due to taxation of private forest land in the United States. Doctoral dissertation, University of Georgia, Athens.

Cushing, T.L., and Newman, D. 2018. Analysis of relative tax burden on nonindustrial private forest landowners in the southeastern United States. J. For. 116(3): 228-235. doi:10.1093/jofore/fvx013.

Engle, R.F. 1982. Autoregressive conditional heteroscedasticity with estimates of the variance of United Kingdom inflation. Econometrica, 50(4): 987-1007. doi:10.2307/1912773

Fama, E.F., and French, R.K. 1993. Common risk factors in the returns on stocks and bonds. J. Financ. Econ. 33: 3-56. doi:10.1016/0304-405X(93)90023-5.

Fernholz, K., Bowyer, J., and Howe, J. 2007. TIMOs \& REITs. What, why, \& how they might impact sustainable forestry. Dovetail Partners, Inc. pp. 13.

Friday, H.S., Sirmans, G.S., and Conover, C.M. 1999. Ownership structure and the value of the firm: The case of REITs. J. Real Estate Res. 17(1): 71-90. doi:10.1080/ 10835547.1999.12090967.

Fu, C.H. 2017. Timberland investments: A primer. Timberland Investment Resources. 27.

Hiegel, A., Siry, J., Bettinger, P., and Mei, B. 2020. Timberland transaction costs and due diligence: A literature review and assessment of research needs. Int. For. Rev. 22(2): 199-210.

Hood, H., Harris, T., Siry, J.P., Baldwin, S., and Smith, J. 2015. US timberland markets: transactions, values, \& market research: 2000 - mid-2015. Timber Mart-South. Athens, GA. pp. 405.

Hunt, T.D. 2012. Securitization of our nation's forests: Legal and practical implications of the timber REIT phenomenon. J. Tax. Investments, 34(4): 47-66.

Internal Revenue Service. 2020. Tax Cuts and Jobs Act, provision 11011 section 199A - qualified business income deduction FAQs. [accessed 10 October 2020].

Karpoff, J.M. 1987. The relation between price changes and trading volume: a survey. J. Financ. Quant. Anal. 22(1): 109-126. doi:10.2307/2330874.

Kuusela, O., and Lintunen, J. 2019. Financial valuation and the optimal rotation of a fully regulated forest. Can. J. For. Res. 49(7): 819-825. doi:10.1139/ cjfr-2018-0371.

La, L., and Mei, B. 2013. Evaluating market efficiency of the US forest industry. For. Prod. J. 63(7/8): 232-237. doi:10.13073/FPJ-D-13-00072.

La, L., and Mei, B. 2015. Portfolio diversification through timber real estate investment trusts: A cointegration analysis. For. Policy Econ. 50: 269-274. doi:10.1016/j.forpol.2014.07.003.

Lerner, M. 2015. Timberland REITs standing tall. Available from https://www. reit.com/timberland-reits-standing-tall [accessed 28 February 2021].

Mei, B. 2015a. Illiquidity and risk of commercial timberland assets in the United States. J. For. Econ. 21(2): 67-78. doi:10.1016/j.jfe.2015.01.003.

Mei, B. 2015b. A pure-play timberland return index based on securitized timber firms. J. Real Estate Portfolio Manage. 21(1): 61-75. doi:10.1080/10835547.2015. 12089972.

Mei, B. 2017. Investment returns of US commercial timberland: insights into index construction methods and results. Can. J. For. Res. 47(2): 226-233. doi:10.1139/cjfr-2016-0186.

Mei, B. 2019. Timberland investments in the United States: a review and prospects. For. Policy Econ. 109: 1-7.

Mei, B., and Clutter, M.L. 2010. Evaluating the financial performance of timberland investments in the United States. For. Sci. 56(5): 421-428.

Mei, B., and Clutter, M.L. 2020. Return and information transmission of public and private timberland markets in the United States. For. Policy Econ. 113: 102092. doi:10.1016/j.forpol.2020.102092.

Mendell, B. 2016. From cigar tax to timberland trusts: A short history of timber REITs and TIMOs. Forest History Today, pp. 32-36.

Mendell, B.C., and Sydor, T. 2008. Farm Bill "TREE Act": implications for the forest industry and timber REITs. Timberland Rep. 10(3): 1-5.

Mendell, B.C., Sydor, T., and Freeman, S. 2007. Introduction to timber real estate investment trusts (timber REITs). Timber Mart South, Market News Q. Q1: 8-10.

Mendell, B.C., Mishra, N., and Sydor, T. 2008. Investor responses to timberlands structured as real estate investment trusts. J. For. 106(5): 277-280.

NAREIT. 2020. About nareit. Available from https://www.reit.com/nareit [accessed 15 June 2020].

National Timber Tax. 2020. Timber related provisions. Available from https:/ www.timbertax.org/research/publiclaws/jobsbill/ [accessed 14 July 2020].

Newell, G., and Eves, C. 2009. The role of U.S. timberland in real estate. J. Real Estate Portfolio Manage. 15(1): 95-106. doi:10.1080/10835547.2009.12089837.

Oswalt, S.N., Smith, W.B., Miles, P.D., and Pugh, S.A. 2019. Forest resources of the United States, 2017. A technical document supporting the forest service 2020 RPA assessment. USDA Forest Service, General Technical Report WO-97. Washington, D.C. p. 219.

Pfeifer, D. 2013. Correlation, tail dependence and diversification. In Robustness complex data structures. Edited by C. Becker, R. Fried, and S. Kuhnt. Springer-Verlag, Berlin, pp. 301-314.

Piao, X., Mei, B., and Xue, Y. 2016. Comparing the financial performance of timber REITs and other REITs. For. Policy Econ. 72: 115-121. doi:10.1016/j. forpol.2016.06.022. 
Piao, X., Mei, B., and Zhang, W. 2017. Long-term event study of timber real estate investment trust conversions. For. Policy Econ. 78: 1-9. doi:10.1016 j.forpol.2016.12.009.

PotlatchDeltic. 2020. Available from https://www.potlatchdeltic.com/ [accessed 19 June 2020].

Prestemon, J.P., Wear, D.N., and Foster, M.O. 2015. The global position of the U.S. forest products industry. USDA Forest Service, Southern Research Station, e-General Technical Report SRS-204. pp. 1-24.

Rayonier, 2020. Available from https://www.rayonier.com/ [accessed 19 June 2020].

Restrepo, H., Zhang, W., and Mei, B. 2020. The time-varying role of timberland in long-term, mixed-asset portfolios under the mean conditional value-at-risk framework. For. Policy Econ. 113: 102136. doi:10.1016/j.forpol.2020.102136.

Ro, S., and Ziobrowski, A.J. 2011. Does focus really matter? Specialized vs. diversified REITs. J. Real Estate Financ. Econ. 42(1): 68-83. doi:10.1007/s11146-0099189-8.

Scholtens, B., and Spierdijk, L. 2010. Does money grow on trees? The diversification properties of U.S. timberland investments. Land Econ. 86(3): 514529. doi:10.3368/le.86.3.514

Sedjo, R.A., and Sohngen, B. 2015. The effects of a federal tax reform on the US timber sector. Resources for the Future. pp. 1-38.

Sharpe, W.F. 1964. Capital asset prices: a theory of market equilibrium under conditions of risk. J. Financ. 19(3): 425-442. doi:10.2307/2977928.

Smith, W.B., Miles, P.D., Perry, C.H., and Pugh, S.A. 2009. Forest resources of the United States, 2007. A technical document supporting the forest service 2010 RPA assessment. USDA Forest Service, General Technical Report WO-78. Washington, D.C. p. 336.

Stevenson, S. 2013. The development and maturing of the US REIT sector. In Real Estate Investment Trusts in Europe. Evolution, regulation, and opportunities for growth. Edited by R. Sotelo and S. McGreal. Springer-Verlag, Berlin, pp. 55-67.
Sun, C. 2013a. Extreme risk of public timber REITs during the global financial crisis. J. Real Estate Portfolio Manage. 19(1): 73-88. doi:10.1080/10835547.2013. 12089938.

Sun, C. 2013b. On the market risk of securitized timberlands. J. For. Econ. 19(2): 110-127. doi:10.1016/j.jfe.2012.11.002.

Sun, C. 2013c. Price variation and volume dynamics of securitized timberlands. For. Policy Econ. 27: 44-53. doi:10.1016/j.forpol.2012.09.017.

Sun, C., and Zhang, D. 2001. Assessing the financial performance of forestryrelated investment vehicles : Capital asset pricing model vs. arbitrage pricing theory. Am. J. Agric. Econ. 83(3): 617-628. doi:10.1111/0002-9092.00182.

Sun, C., Rahman, M.M., and Munn, I.A. 2013. Adjustment of stock prices and volatility to changes in industrial timberland ownership. For. Policy Econ. 26: 91-101. doi:10.1016/j.forpol.2012.08.003.

Wan, Y., Mei, B., Clutter, M.L., and Siry, J.P. 2013. Assessing the inflation hedging ability of timberland assets in the United States. For. Sci. 59(1): 93-104. doi:10.5849/forsci.11-029.

Wechsler, S.A. 2013. The role of REITs in strategic investment portfolios. In Real Estate Investment Trusts in Europe. Evolution, Regulation, and Opportunities for Growth. Edited by R. Sotelo and S. McGreal. Springer-Verlag, Berlin, pp. 43-53.

WRDS. 2020. Wharton research data services. The Wharton School at the University of Pennsylvania.

Weyerhaeuser. 2020. Available from https://www.weyerhaeuser.com/ [accessed 19 June 2020].

Yao, W., and Mei, B. 2015. Assessing forestry-related assets with the intertemporal capital asset pricing model. For. Policy Econ. 50: 192-199. doi:10.1016/j. forpol.2014.06.006

Yao, W., Mei, B., and Clutter, M.L. 2014. Pricing timberland assets in the United States by the arbitrage pricing theory. For. Sci. 60(5): 943-952. doi:10.5849/ forsci.13-023. 